\title{
Impact of oral capsule of Peganum harmala on alleviating urinary symptoms in men with benign prostatic hyperplasia; a randomized clinical trial
}

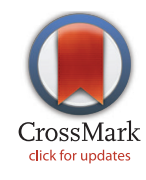

\author{
Majid Shirani-Boroujeni ${ }^{1}$, Saeed Heidari-Soureshjani ${ }^{2}$, Zahra Keivani Hafshejani ${ }^{3^{*}}$ \\ ${ }^{1}$ Department of Surgery, Shahrekord University of Medical Sciences, Shahrekord, Iran \\ ${ }^{2} \mathrm{MSc}$, Research and Technology Deputy, Shahrekord University of Medical Sciences, Shahrekord, Iran \\ ${ }^{3}$ Department of Nursing, Shahrekord University of Medical Sciences, Shahrekord, Iran
}

\section{AR T I C L E I N F O}

Article Type:

Original

\section{Article History:}

Received: 4 October 2016

Accepted: 12 December 2016

Published online: 20 December 2016

Keywords:

Lower urinary tract

Tamsulosin

Benign prostatic hyperplasia

Peganum harmala

\begin{abstract}
A B S T R A C T
Introduction: Benign prostatic hyperplasia (BPH) is considered as a major cause of lower urinary tract symptoms (LUTS) in older men and its most common sign is nocturia. Objectives: This study aimed to determine the effect of the seeds of Peganum harmala compared with tamsulosin on alleviating urinary symptoms in patients with BPH.

Patients and Methods: In this single blind clinical trial study, 90 patients diagnosed with BPH and LUTS, based on international prostate standard survey (IPSS) were divided into three groups. The first group was received oral capsule of $P$. harmala, the second group was administered tamsulosin with oral $P$. harmala seed and the third group was received tamsulosin drug and they were evaluated after 4 weeks.

Results: The results showed that the difference between mean scores of IPSS was significant after the intervention $(P=0.001)$. Besides, the mean of IPSS in the three groups was significantly different $(P=0.001)$ (the first group $41.9 \pm 5.3$, the second group $21.0 \pm 4.4$, the third group $16.5 \pm 3.7$ respectively). However, after the intervention, patients in the second group had the lowest average on most indicators of IPSS but the difference was only significant about urinary frequency, nocturia and intermittency $(P<0.05)$.

Conclusion: Application of Peganum harmala seed can be useful in reducing urinary symptoms in patients with BPH.
\end{abstract}

Implication for health policy/practice/research/medical education:

Peganum harmala can be administered as a herbal remedy for improving urinary symptoms of benign prostate enlargement. Please cite this paper as: Shirani-Boroujeni M, Heidari-Soureshjani S, Keivani Hafshejani Z. Impact of oral capsule of Peganum harmala on alleviating urinary symptoms in men with benign prostatic hyperplasia; a randomized clinical trial. J Renal Inj Prev. 2017;6(2):127-131. DOI: 10.15171/jrip.2017.25.

\section{Introduction}

Benign prostatic hyperplasia (BPH) is occurred due to the proliferation of irregular connective tissue, glandular epithelium and smooth muscle in the prostate transition zone (1).

The disease involves tens of millions of elderly men in the world and as growing public health problem causes urinary retention (bladder outlet obstruction) (2).

Clinically, the disorder is diagnosed as lower urinary tract symptoms (LUTS) (3). Hence, the development of urinary tract symptoms is considered as $\mathrm{BPH}$ progression causing problems such as loss of quality of life of patients with acute urinary retention, recurrent infections of the urinary tract, urinary incontinence, calcium deposits in the bladder, kidney obstructive failure, BPH-related surgery (4) and probably threaten the patients' life (5). The treatment recommended preventing $\mathrm{BPH}$ progression was consisted of the combination of $5 \alpha$-reductase inhibitors and a blocker (4). Tamsulosin is of the third generation of alpha-blockers and is regarded as one of the most frequent drugs used for $\mathrm{BPH}$. Its long-term consumption is followed by complications such as orthostatic hypotension, dizziness, headache, asthenia, runny nose and ejaculation problems as well $(4,6)$. In recent years, the use of herbal medicines and natural products is increasing because of fewer side effects $(7,8)$. 
On the other hand, effect of various herbal medicines on $\mathrm{BPH}$ and its associated complications has been reported in various studies (9-11).

Peganum harmala L. which belongs to Zygophyllaceae family, has long been focused in Iranian traditional medicine. $P$. harmala is a wild and perennial plant grown in a semi-arid, steppe regions and sandy soils in the Eastern Mediterranean region (12-14).

The seeds of this plant are rich in carbohydrates, lipids, proteins, minerals, alkaloids and amino acids. Active ingredients of this plant include mainly beta-carboline and quinazoline alkaloids that were particularly accumulated in its seeds and roots (14).

The properties of this plant were consisted of positive effects on cardiovascular disease, nervous system, gastrointestinal complications, bone, diabetes, immune system disorders, antimicrobial activity inducing abortion, anti-inflammatory, anti-cancer and anti-proliferative activities (14). However, it should be noted that excessive consumption of this herb and its illegal prescription can also cause various complications and toxicity in consumers (11).

Although diagnostic methods and new treatments for $\mathrm{BPH}$ management have been developed (15), there is no effective treatment with few side effects for this disorder.

\section{Objectives}

Given the importance of this plant in herbal medicine and limitations of clinical studies, this study was conducted to determine the effect of edible seeds of $P$. harmala on nocturia in patients with benign prostatic hyperplasia referred to urology clinic affiliated with Ayatollah-Kashani hospital in Shahrekord, Iran.

\section{Patients and Methods}

Subjects

This double-blind clinical trial study was carried out on 90 patients diagnosed with benign prostatic hyperplasia based on international prostate standard survey (IPSS). Besides, criteria such as the size of the prostate, prostatespecific antigen (PSA), history of previous disease, history of previous surgery were considered. Inclusion criteria were patients with benign prostatic hyperplasia. Exclusion criteria were patients who were candidate of surgery, obvious anatomic or functional anomaly in the urinary tract, thyroid disorder, prostate cancer, patients with mental disorders, active or chronic infections and sensitivity to the drug.

Patients were divided into three groups. The sampling method was random allocation.

The first group (32 patients) treated with oral capsules of $P$. harmala seed (containing one gram of Pe. harmala), the second group (29 patients) was received conventional therapy of alpha blockers (tamsulosin) in combination with oral administration of $P$. harmala and the third group (29 patients) were prescribed conventional therapy of alpha blockers (tamsulosin) alone. Therapeutic dose used in this study was $1 \mathrm{~g}$. However, due to the hepatotoxicity effect of $P$. harmala, hepatic factors such as aspartate aminotransferase (AST), alanine aminotransferase (ALT), and alkaline phosphatase (ALP) in all patients were checked and after 4 weeks were examined.

\section{Ethical issues}

The research followed the tenets of the Declaration of Helsinki; informed consent was obtained, and the research was approved by the ethics committee of Shahrekord University of Medical Sciences. In this study, the full description of the processes and the importance of the study were explained to the participants who had volunteered and were selected (IRCT code\# IRCT2014091419151N1, and ethical approval code\# 92-5-4).

\section{Statistical analysis}

The data were analyzed by SPSS 22 using descriptive tests, Kruskal-Wallis, Wilcoxon and Mann-Whitney U tests. A $P$ value less than 0.05 was considered as statistically significant.

\section{Results}

In this study, 90 patients with benign prostatic hypertrophy were divided into three groups. Groups were not significantly different regarding to mean age, prostate size by ultrasound and PSA levels $(P>0.05)$.

Of the 90 patients, in $P$. harmala group 24 patients (75\%), in tamsulosin and P. harmala group $24(82.8 \%)$ and in tamsulosin group 22 patients $(75.9 \%)$ had no previous medical history. The history of surgery was 27 (84.4\%) in the $P$. harmala group, $26(89.7 \%)$ in tamsulosin and $P$. harmala group. Twenty-six $(89.7 \%)$ in tamsulosin group had no history of previous surgery.

The average size of the prostate in $P$. harmala group, $P$. harmala and tamsulosin group, and tamsulosin group was $25.81 \pm 14.8 \mathrm{~cm}^{3}, 25.71 \pm 11.3 \mathrm{~cm}^{3}, 75.03 \pm 13.65 \mathrm{~cm}^{3}$, respectively. The serum level of PSA in $P$. harmala group, $P$. harmala and tamsulosin group, and tamsulosin group was $1.37 \pm 0.98 \mathrm{ng} / \mathrm{mL}, 1.64 \pm 0.70 \mathrm{ng} / \mathrm{mL}$, and $1.18 \pm 0.77$ $\mathrm{ng} / \mathrm{mL}$ respectively.

Scores distribution in the scoring questionnaire was not normal. Thus, to compare the scores of three groups before and after the intervention, the Kruskal-Wallis test was used. Before the intervention, there was no significant difference in the average of the three groups $(P=0.347)$, which indicated that the groups were matched. However, significant differences in mean scores after the intervention was detected $(P=0.001)$.

The lowest score of the questionnaire after the intervention in tamsulosin and P. harmala groups was $12.0 \pm 4.4$ and most score was related to tamsulosin group with 16.5 \pm 3.7 .

Besides, it was shown that $P$. harmala and tamsulosin group with an IPSS average of $12.0 \pm 4.4, P$. harmala with an IPSS average $14.9 \pm 5.3$ and tamsulosin group with an IPSS average of $16.5 \pm 3.7$ were significantly 
different; however, P. harmala and tamsulosin group and tamsulosin group were not significantly different. In addition, it was indicated that in three groups before and after the intervention, mean scores were significantly different $(P<0.001$; Table 1$)$.

Assessment of the survey scores for all groups before and after the intervention showed that they had significant difference $(P<0.05)$ and variables including urinary frequency and nocturia after the intervention, respectively with $(P=0.002)$ and $(P=0.001)$ in each three groups were significantly different. There was a significant difference among three groups in terms of intermittency symptoms $(P=0.002$; Table 2).

\section{Discussion}

This study examined the effect of $P$. harmala seed in benign prostatic hyperplasia.

In this study, combination of $P$. harmala with tamsulosin had more effect on alleviating mean of urinary symptoms than other groups, although this difference was significant in some cases. Besides, patients in $P$. harmala group compared to the third group had more average reduction in urinary symptoms after the intervention. Despite the fact that in some studies $P$. harmala has been known as a diuretic herb (16), in this study, it was suggested that it had a positive effect on variables such as frequent urination of patients.

On the other hand, the mechanism of action of benign prostatic hyperplasia is unknown, however, some studies considered the following factors including oxidative stress (17) inflammation (5) and vasoconstriction (18) in the occurrence of the disease. It was shown that ethanol

Table 1. Comparison of IPSS before and after intervention in all three groups based on the total survey score

\begin{tabular}{lccc}
\hline & Tamsulosin group & $\begin{array}{c}\text { Peganum harmala and } \\
\text { Tamsulosin group }\end{array}$ & Peganum harmala group \\
\cline { 2 - 4 } & Mean \pm SD & Mean \pm SD & Mean \pm SD \\
\hline Before intervention & $22.6 \pm 3.8$ & $21.5 \pm 3.6$ & $21.2 \pm 4.4$ \\
After intervention & $16.5 \pm 3.7$ & $12.0 \pm 4.4$ & $14.9 \pm 5.3$ \\
$P$ value & $<0.001$ & $<0.001$ & $<0.347$ \\
\hline
\end{tabular}

Table 2. Comparison of IPSS before and after intervention in all three groups based on the survey questions

\begin{tabular}{|c|c|c|c|c|}
\hline \multirow[b]{2}{*}{ Groups } & \multicolumn{3}{|c|}{ Groups } & \multirow[b]{2}{*}{$P$ value } \\
\hline & $\begin{array}{l}\text { Peganum harmala } \\
\text { group (Mean } \pm S D)\end{array}$ & $\begin{array}{c}\text { Peganum harmala and Tamsulosin } \\
\text { group (Mean } \pm S D)\end{array}$ & $\begin{array}{c}\text { Tamsulosin group } \\
\text { (Mean } \pm \text { SD) }\end{array}$ & \\
\hline \multicolumn{5}{|l|}{ Incomplete discharge } \\
\hline Before & $2.68 \pm 1.89$ & $2.93 \pm 1.70$ & $2.68 \pm 1.58$ & 0.826 \\
\hline After & $2 \pm 1.70$ & $1.86 \pm 1.30$ & $2.27 \pm 1.46$ & 0.568 \\
\hline$P$ value before and after intervention & $<0.001$ & $<0.001$ & $<0.001$ & \\
\hline \multicolumn{5}{|l|}{ Urinary frequency } \\
\hline Before & $3.65 \pm 1$ & $2.62 \pm 1.42$ & $3.51 \pm 0.82$ & 0.078 \\
\hline After & $2.43 \pm 1.01$ & $1.68 \pm 1.19$ & $2.75 \pm 0.91$ & 0.002 \\
\hline$P$ value before and after intervention & $<0.001$ & $<0.001$ & $<0.001$ & \\
\hline \multicolumn{5}{|l|}{ Intermittency } \\
\hline Before & $2.28 \pm 1.3$ & $2 \pm 1.33$ & $2.96 \pm 1.14$ & 0.094 \\
\hline After & $1.93 \pm 1.13$ & $1.10 \pm 0.85$ & $2.17 \pm 0.88$ & 0.001 \\
\hline$P$ value before and after intervention & 0.008 & $<0.001$ & $<0.001$ & \\
\hline \multicolumn{5}{|l|}{ Urgent need to urinate } \\
\hline Before & $2.87 \pm 1.56$ & $2.82 \pm 1.25$ & $2.89 \pm 1.17$ & 0.98 \\
\hline After & $1.96 \pm 1.06$ & $1.86 \pm 0.63$ & $2.41 \pm 0.98$ & 0.057 \\
\hline$P$ value before and after intervention & $<0.001$ & $<0.001$ & $<0.001$ & \\
\hline \multicolumn{5}{|l|}{ Weak flow of urine } \\
\hline Before & $3.56 \pm 1.43$ & $3.82 \pm 1.03$ & $4.10 \pm 1.04$ & 0.217 \\
\hline After & $2.68 \pm 1.37$ & $2.34 \pm 1.14$ & $2.06 \pm 1.06$ & 0.141 \\
\hline$P$ value before and after intervention & $<0.001$ & $<0.001$ & $<0.001$ & \\
\hline \multicolumn{5}{|l|}{ Straining to urinate } \\
\hline Before & $2.46 \pm 1.07$ & $3.20 \pm 1.26$ & $2.58 \pm 1.45$ & 0.128 \\
\hline After & $1.81 \pm 1.17$ & $1.86 \pm 1.21$ & $2.96 \pm 1.05$ & 0.871 \\
\hline$P$ value before and after intervention & $<0.001$ & $<0.001$ & $<0.001$ & \\
\hline \multicolumn{5}{|l|}{ Nocturia } \\
\hline Before & $3.68 \pm 1.25$ & $4.13 \pm 0.91$ & $3.86 \pm 0.74$ & 0.219 \\
\hline After & $2.06 \pm 1.13$ & $1.34 \pm 0.72$ & $2.89 \pm 0.72$ & 0.001 \\
\hline$P$ value before and after intervention & $<0.001$ & $<0.001$ & $<0.001$ & \\
\hline
\end{tabular}


extract of $P$. harmala seed can inhibit lipid peroxidation and improve the antioxidant property of $P$. harmala (19). Bielli et al found that antioxidants are caused to widen arteries and have relaxant effect (20). In this study, according to relieve symptoms in patients using $P$. harmala and tamsulosin, it seems that the vasodilation effect of $P$. harmala triggered to improve symptoms. Bensalem et al have shown that anti-inflammatory properties of $P$. harmala are caused by the existence of $\beta$-carboline alkaloid that is due to inhibit myeloperoxidase and other factors involved in inflammation (21).

It is known that anti-inflammatory properties of this plant are caused by the inhibitory effect of some of inflammatory mediators such as prostaglandin E2 (PGE2) and tumor necrosis factor alpha (TNF- $\alpha$ ) (22). In another study, it was found that alkaloid in Peganum harmala has relaxant effects on mice aorta (23).

Therefore, given to the afore-mentioned therapeutic properties, it is not far reached that $P$. harmala can be effective in reducing urinary symptoms in patients with benign prostatic hyperplasia. However, these therapeutic properties of $P$. harmala are more due to its alkaloid compounds such as harmalol, harmaline and harmine used in the treatment of cancer and benign prostatic hyperplasia. In addition, the other healing properties of this plant make it popular in the Iranian traditional medicine (14).

Other alkaloids found in P. harmala like vasicinone have anti-cell proliferation and can cause cytotoxicity in tumor cells in vitro (24). Of course, it should also be noted that $\beta$-carboline alkaloids in $P$. harmala can create toxicity at high doses (25), hence this herb should be administered in the effective therapeutic and non-toxic dose.

\section{Conclusion}

In this study, most improvement of the symptoms was related to nocturia, urinary frequency and intermittency. According to the findings of this study, P. harmala can be used as a herbal drug for improving urinary symptoms of benign prostate enlargement considering its toxic dose.

\section{Limitations of the study}

Lack of extraction and isolation of the main active compound of the plant and some defects in design of the study are the limitation of the study.

\section{Authors' contribution}

ZK; Study concept and design, acquisition of data, analysis and interpretation of data. SH; drafting of the manuscript. MS; critical revision of the manuscript for important intellectual content, administrative, technical, and material support.

\section{Conflicts of interest}

The authors declared that there was no conflict of interest.

\section{Ethical considerations}

Ethical issues (including plagiarism, data fabrication, double publication) have been completely observed by the authors.

\section{Funding /support}

Shahrekord University of Medical Sciences supported this research financially (Grant \# 1462, 2015).

\section{References}

1. Auffenberg GB, Helfand BT, McVary KT. Established medical therapy for benign prostatic hyperplasia. Urol Clin North Am. 2009;36:443-59. doi: 10.1016/j.ucl.2009.07.004.

2. Patel ND, Parsons JK. Epidemiology and etiology of benign prostatichyperplasia and bladder outlet obstruction. Indian J Urol. 2014;30:170-6. doi: 10.4103/0970-1591.126900.

3. Ding H, Du W, Hou ZZ, Wang HZ, Wang ZP. Silodosin is effective for treatment of LUTS in men with BPH: a systematic review. Asian J Androl. 2013;15:121-8. doi: 10.1038/ aja.2012.102.

4. Spatafora S, Casarico A, Fandella A, Galetti C, Hurle R, Mazzini E, et al. Evidence-based guidelines for the treatment of lower urinary tract symptoms related to uncomplicated benign prostatic hyperplasia in Italy: updated summary from AURO.it. Ther Adv Urol. 2012;4:279-301. doi: $10.1177 / 1756287212463112$.

5. Izumi $\mathrm{K}$, Li L, Chang C. Androgen receptor and immune inflammation in benign prostatic hyperplasia and prostate cancer. Clin Investig (Lond). 2014;4:935-50. doi: 10.4155/ cli.14.77.

6. Roehrborn CG. Efficacy of alpha-adrenergic receptor blockers in the treatment of male lower urinary tract symptoms. Rev Urol. 2009;11:S1-8.

7. de Souza PA, Palumbo A Jr, Alves LM, de Souza VP, Cabral LM, Fernandes PD, et al. Effects of a nanocomposite containing orbignya speciosa lipophilic extract on benign prostatic hyperplasia. J Ethnopharmacol. 2011;135:135-46. doi: 10.1016/j.jep.2011.03.003.

8. Zhang W, Wang X, Liu Y, Tian H, Flickinger B, Empie MW, et al. Effects of dietary flaxseed lignan extract on symptoms of benign prostatic hyperplasia. J Med Food. 2008;11:207-14. doi: 10.1089/jmf.2007.602.

9. Chen J, Xiong CM, Song SS, Han P, Ruan JL. Fraction of macroporous resin from Smilax china L. inhibits testosterone propionate-induced prostatic hyperplasia in castrated rats. J Med Food. 2012;15:646-50. doi: 10.1089/jmf.2011.1968.

10. Shin IS, Lee MY, Ha HK, Seo CS, Shin HK. Inhibitory effect of Yukmijihwang-tang, a traditional herbal formula against testosterone-induced benign prostatic hyperplasia in rats. BMC Complement Altern Med. 2012;12:48. doi: 10.1186/1472-6882-12-48.

11. Moshiri M, Etemad L, Javidi S, Alizadeh A. Peganum harmala intoxication, a case report. Avicenna J Phytomed. 2013;3(3):288-92.

12. Wanntorp L, Louis P. Swedish museum of natural history. In: Wanntorp L, ed. Flowers on the Tree of Life. Series: Systematics Association Special Volume Series. 1st ed. UK: Cambridge University Press; 2011:326.

13. Frison G, Favretto D, Zancanaro F, Fazzin G, Ferrara SD. A case of beta-carboline alkaloid intoxication following ingestion of Peganum harmala seed extract. Forensic Sci Int. 2008;179(2-3):e37-43. doi: 10.1016/j.forsciint.2008.05.003.

14. Moloudizargari M, Mikaili P, Aghajanshakeri S, Asghari $\mathrm{MH}$, Shayegh J. Pharmacological and therapeutic effects of 
Peganum harmala and its main alkaloids. Pharmacogn Rev. 2013;7:199-212. doi: 10.4103/0973-7847.120524.

15. Tanguay S, Awde M, Brock G, Casey R, Kozak J, Lee J, et al. Diagnosis and management of benign prostatic hyperplasia in primary care. Can Urol Assoc J. 2009;3:S92-100.

16. Mina CN, Farzaei MH, Gholamreza A. Medicinal properties of Peganum harmala L. in traditional Iranian medicine and modern phytotherapy: a review. J Tradit Chin Med. 2015;35:104-9.

17. Luo J, Dunn T, Ewing C, Sauvageot J, Chen Y, Trent J, et al. Gene expression signature of benign prostatic hyperplasia revealed by cDNA microarray analysis. Prostate. 2002;51:189200.

18. Lu HG, Liu LF, Ren LM, Zhao QH, Duan LH, Zhang XY. Effects of doxazosin enantiomers on alpha-adrenoceptors of isolated rabbit blood vessels. Yao Xue Xue Bao. 2007;42:14551.

19. Bourogaa E, Jarraya RM, Damak M, Elfeki A. Hepatoprotective activity of Peganum harmala against ethanol-induced liver damages in rats. Arch Physiol Biochem. 2015;121:62-7. doi: 10.3109/13813455.2015.1016974.

20. Bielli A, Scioli MG, Mazzaglia D, Doldo E, Orlandi A. Antioxidants and vascular health. Life Sci. 2015;143:209-16. doi: $\quad$ 10.1016/j.lfs.2015.11.012.

21. Bensalem S, Soubhye J, Aldib I, Bournine L, Nguyen AT, Vanhaeverbeek M, et al. Inhibition of myeloperoxidase activity by the alkaloids of Peganum harmala L. (Zygophyllaceae). J Ethnopharmacol. 2014;154:361-9. doi: 10.1016/j. jep.2014.03.070.

22. Bremner P, Rivera D, Calzado MA, Obon C, Inocencio C, Beckwith C, et al. Assessing medicinal plants from SouthEastern Spain for potential anti-inflammatory effects targeting nuclear factor-Kappa B and other pro-inflammatory mediators. J Ethnopharmacol. 2009;124:295-305. doi: 10.1016/j.jep.2009.04.035.

23. Astulla A, Zaima K, Matsuno Y, Hirasawa Y, Ekasari W, Widyawaruyanti A, et al. Alkaloids from the seeds of Peganum harmala showing antiplasmodial and vasorelaxant activities. J Nat Med. 2008;62:470-2. doi: 10.1007/s11418-008-0259-7.

24. Lamchouri F, Zemzami M, Jossang A, Abdellatif A, Israili ZH, Lyoussi B. Cytotoxicity of alkaloids isolated from Peganum harmala seeds. Pak J Pharm Sci. 2013;26:699-706.

25. Herraiz T, González D, Ancín-Azpilicueta C, Arán VJ, Guillén H. $\beta$-Carboline alkaloids in Peganum harmala and inhibition of human monoamine oxidase (MAO). Food Chem Toxicol. 2010;48:839-45.

Copyright (C) 2017 The Author(s); Published by Nickan Research Institute. This is an open-access article distributed under the terms of the Creative Commons Attribution License (http://creativecommons.org/licenses/by/4.0), which permits unrestricted use, distribution, and reproduction in any medium, provided the original work is properly cited. 